\title{
Media Promosi Gudnyus.id Berbasis Motion Graphic
}

\author{
Moch Calvin Ali ${ }^{1}$, Arta Uly Siahaan ${ }^{2}$ \\ * Informatics Engineering, Batam State Polytechnic \\ ** Multimedia and Network Engineering, Batam State Polytechnic
}

\begin{tabular}{|c|c|}
\hline Article Info & ABSTRACT \\
\hline Article history: & \multirow{15}{*}{$\begin{array}{l}\text { Gudnyus.id is an online media and social news website concept. To support its } \\
\text { popularity and bring out its existence, a promotional medium is needed. Based } \\
\text { on the questionnaire that the author has distributed online via google form with } \\
\text { the target of general public respondents in the urban center of Batam, } \\
\text { information is obtained from the questionnaire, } 60.6 \% \text { of the public does not } \\
\text { know while } 39.4 \% \text { knows, but only sees Gudnyus. Id posters or flyers on social } \\
\text { media. Consequently, Gudnyus.id requires promotional support in the form of } \\
\text { video, which is chosen because Gudnyus.id has no promotional support in the } \\
\text { form of videos, particularly animated videos. In the production of promotional } \\
\text { videos, the author uses the Villamil-Molina search method to support the } \\
\text { design. There are five phases: development, pre-production, production, } \\
\text { postproduction and delivery. The author uses the epic model method as an } \\
\text { analysis to test the efficacy of Gudnyus.id's promotional media based on } \\
\text { motion graphs. The information in the promotional video includes an } \\
\text { introduction to Gudnyus.id as an online media, website heading, and the social } \\
\text { media used by Gudnyus.id to transmit the information. from the output of the } \\
\text { efficacy analysis using epic model, it's known that the promotional video of } \\
\text { Gudnyus.id based on the movement charts was found to be effective with an } \\
\text { average value of } 4.05 \text { empathy, } 4.26 \text { persuasion, } 4.0 \text { impact, } 4.22 \\
\text { Communication. }\end{array}$} \\
\hline Received Jun $12^{\text {th }}, 2021$ & \\
\hline Revised Jun 20 $0^{\text {th }}, 2021$ & \\
\hline Accepted Jul 26 $6^{\text {th }}, 2021$ & \\
\hline & \\
\hline Keyword: & \\
\hline Motion Graphic & \\
\hline Video & \\
\hline Promotion & \\
\hline Gudnyus.id & \\
\hline Epic Model & \\
\hline Villamil-Molina & \\
\hline & \\
\hline & \\
\hline & \\
\hline
\end{tabular}

\section{PENDAhuluan}

Saat ini Pertumbuhan teknologi dan informasi saat ini semakin cepat, dibuktikan dengan hadirnya berbagai macam bentuk media baik itu cetak maupun elektronik. Menempatkan teknologi dan informasi sebagai media pembelajaran, penyebaran informasi, dan media periklanan atau promosi dari sebuah produk. Promosi merupakan salah satu teknologi komunikasi yang dikomunikasikan dalam bentuk media melalui perantara [1]. Media promosi merupakan sarana promosi produk melalui televisi, radio, koran, majalah, poster, brosur, flyer, website dan lainnya, bertujuan untuk menghubungkan antara pemberi informasi dan penerima informasi [2].

Di Indonesia media online bermula pada tahun 1990-an, awalnya media online adalah hobi bagi sejumlah orang yang tertarik dalam membangun jaringan komputer [3]. Lambat laun perkembangan media online semakin pesat, dibuktikan dengan hadirnya media online pertama yaitu Republika.co.id pada 17 Agustus1994, dan terus bermunculan hingga saat ini.

Salah satu contoh media online saat ini adalah Gudnyus.id. yang didirikan pada tahun 2018 di Batam. Gudnyus.id bergerak dalam bidang Social news site, dengan konten yang dikemas secara inovatif, kreatif dan edukatif, sebagai media bacaan alternatif. Gudnyus.id memiliki media promosi yang sangat terbatas dikarenakan baru didirikan, hal ini menyebabkan masyarakat belum mengetahui keberadaan Gudnyus.id. Hal itu dibuktikan dengan dilemparnya kuesioner secara online melalui google form dengan responden masyarakat umum di kota Batam, didapatlah informasi, $60.6 \%$ masyarakat tidak mengetahui sedangkan $39.4 \%$ mengetahui sebatas melihat poster atau flyer Gudnyus.id di media sosial.

Guna menunjang keberadaan dan pengenalan media online Gudnyus.id diperlukan media promosi tambahan. Dimana salah satu bentuk media promosi yang belum ada ialah video animasi, dari sana penulis diminta untuk membuat video animasi berupa motion .

Motion graphic adalah media visual yang menggabungkan video dan desain grafis. Ini dapat dicapai dengan berfokus pada berbagai aspek seperti animasi seperti 2D, 3D, video, tipografi, fotografi, musik, ilustrasi [4]. 
Pada pembuatan penelitian digunakan beberapa penelitian sebelumnya berfungsi sebagai referensi dan pembanding untuk penulis: Budi prio utomo mengimplementasikan motion graphic pada media promosi Smk Animasi Bina Nusantara Batam yang digunakan untuk menjelaskan dan mempromosikan kepada khalayak ramai mengenai Smk tersebut, dengan menggunakan metode perancangan Villamil-Molina (Budi Prio Utomo, 2018). Shelly Puji Lestary juga mengimplementasikan motion graphic pada implementasi dan analisis motion graphic yang berfungsi sebagai media promosi Batam Pos yang digunakan untuk memperkenalkan website dari Batam Pos menggunakan metode Luther Sutopo (Shelly Puji Lestary, 2018). Mifta Fadya melakukan pembuatan motion graphic sebagai media promosi pada campaign "Kado Blanja" di media sosial PT.Metraplasa - Blanja.com dengan menggunakan metode perancangan Villamil-Molina yang berfungsi untuk mempromosikan Kado Blanja (Mifta Fadya, 2018). Sedangkan penulis membuat video promosi dengan judul Media Promosi Gudnyus.id Berbasis motion graphic menggunakan metode perancangan VillamilMolina.

\section{METODE PENELITIAN}

Dalam perancangan video promosi digunakan metode Villamil-Molina, metode ini memiliki beberapa tahap pengembangan seperti: Pengembangan,,Pra-produksi, Produksi, Pasca-Produksi dan Publikasi [5].

\section{Pengembangan}

Tahap ini konsep produk multimedia yang akan dikembangkan akan terbentuk sesuai dengan ide yang telah ditentukan dan akan menentukan maksud dan tujuan dari produk yang dibuat. Dimana pada pembentukan ide dimulai dengan menentukan judul yang diambil dari permasalahan yang ada yaitu media promosi Gudnyus.id berbasis motion graphic, bertujuan sebagai media promosi untuk memperkenalkan Gudnyus.id kepada anak muda usia 19-34 tahun dan masyarakat umum usia 35-60 tahun.

\section{Pra-Produksi}

Pada tahap pre-production dilakukan, pengembangan ide menjadi bentuk visual, mempersiapkan peralatan yaitu software dan hardware yang diperlukan, serta mengembangkan jalan cerita, penulisan narasi, storyboard, pembuatan asset (Desain objek, icon, sketsa karakter, dan background). Seperti yang ditunjukkan pada Gambar 1-3 dan Tabel 1-3

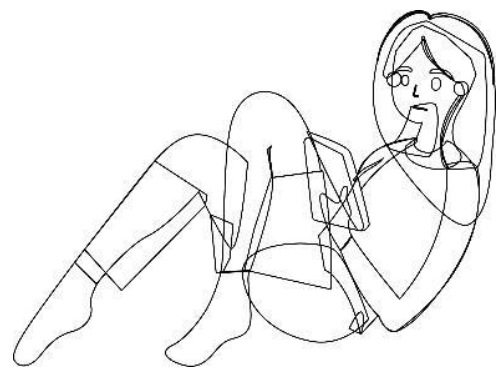

Gambar 1. Sketsa karakter

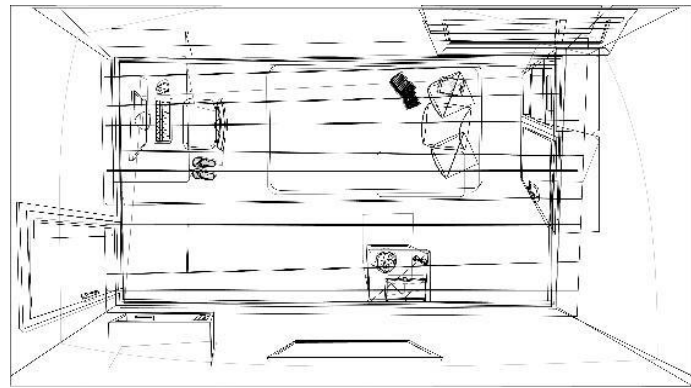

Gambar 2. Desain background

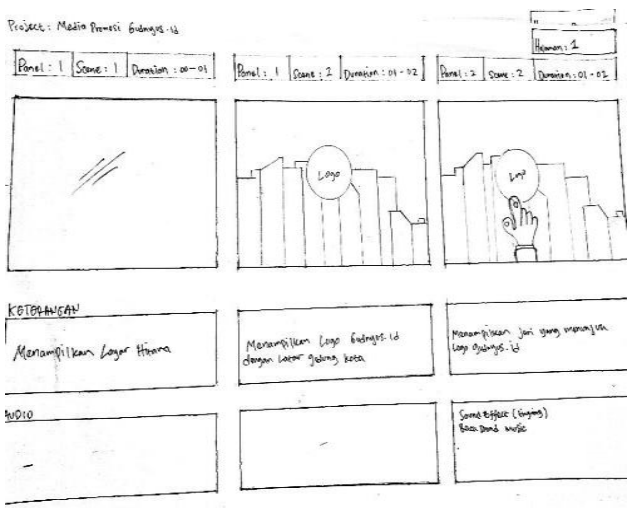

Gambar 3. Desain Storyboard

Tabel 1. Desain Objek

Tabel 3. Narasi 


\begin{tabular}{|c|c|c|l|}
\hline No. & Nama & Objek & $\begin{array}{l}\text { Keteranga } \\
\mathbf{n}\end{array}$ \\
\hline 1. & $\begin{array}{c}\text { Handph } \\
\text { one }\end{array}$ & $\begin{array}{l}\text { Sketsa } \\
\text { Gambar } \\
\text { handphone } \\
\text { yang akan } \\
\text { digunakan }\end{array}$ \\
\hline
\end{tabular}

Tabel 2. Desain Icon

\begin{tabular}{|c|c|c|l|}
\hline No. & Nama & Objek & $\begin{array}{l}\text { Keteran } \\
\text { gan }\end{array}$ \\
\hline 1. & Facebook & $\begin{array}{l}\text { Sketsa } \\
\text { untuk } \\
\text { melamba } \\
\text { ngkan } \\
\text { ikon } \\
\text { Facebook }\end{array}$ \\
\hline 2. & Youtube & & $\begin{array}{l}\text { Sketsa } \\
\text { untuk } \\
\text { melamba } \\
\text { ngkan } \\
\text { ikon } \\
\text { Youtube }\end{array}$ \\
\hline
\end{tabular}

\begin{tabular}{|c|l|l|}
\hline Scene & \multicolumn{1}{|c|}{ Narasi Suara } & \multicolumn{1}{|c|}{ Narasi Visual } \\
\hline 3. & $\begin{array}{l}\text { Bosan dengan } \\
\text { hari mu yang } \\
\text { gitu-gitu } \\
\text { aja? }\end{array}$ & $\begin{array}{l}\text { Menampilkan } \\
\text { orang yang } \\
\text { sedang } \\
\text { tiduran di } \\
\text { kamar sembari } \\
\text { bermain } \\
\text { handphone }\end{array}$ \\
\hline
\end{tabular}

Tabel 4. Spesifikasi Hardware dan Software

\begin{tabular}{|c|ll|}
\hline Perangkat & & \multicolumn{1}{l|}{ Keterangan } \\
& & \\
\hline Hardware & - & Laptop \\
& - & Kapasitas Memori Ram \\
& & 4 GB \\
& - & VGA AMD Radeon R5 \\
& - & Speaker \\
& - & Mikrofon \\
\hline Software & - & Windows 10 \\
& - & Adobe After Effect Cc \\
& - & Adobe Illustrator Cc \\
& - & Adobe Premiere Cc \\
& - & Adobe Media Encoder \\
\hline
\end{tabular}

\section{Produksi}

Hal yang dilakukan pada tahap ini adalah melakukan proses pengembangan desain grafis seperti melakukan tracing, dan coloring dari sketsa yang dibuat, pengembangan sketsa menjadi animasi memulai proses animating dilanjutkan dengan proses, dubbing, editing dan rendering video hingga menjadi sebuah produk. Tahapan tracing, coloring, animation, dubbing, editing, dan rendering ditunjukkan pada Gambar 4-6 dan 11-13.

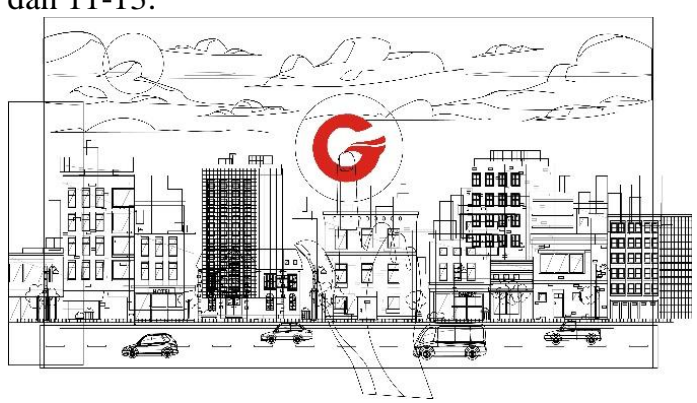

Gambar 4. Proses Tracing

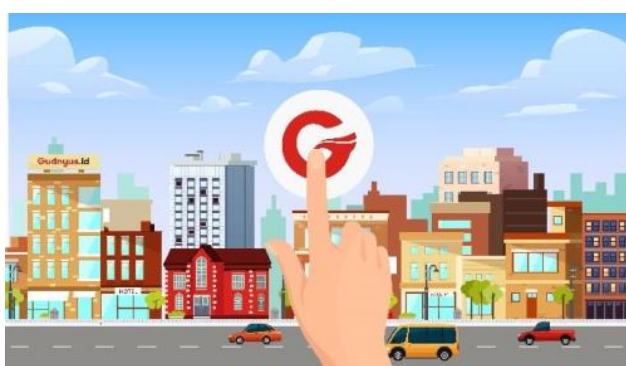

Gambar 5. Proses Coloring

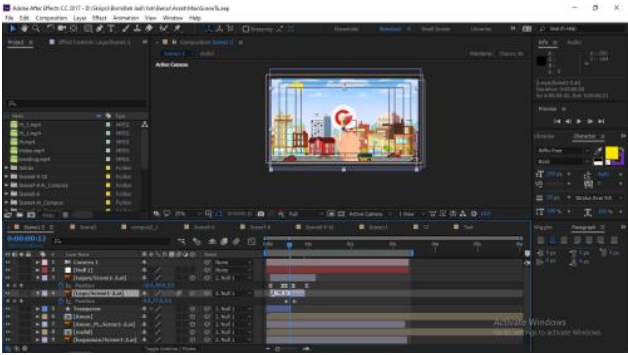

Gambar 6. Proses Animation

Dalam proses animation diterapkan aspek-aspek motion graphic seperti Aspek spatial merupakan aspek yang berkaitan dengan position, scale dan rotation yang digunakan dalam mempengaruhi suatu objek dengan 
objek lainnya dalam perpindahan arah, gerakan dan ukuran. Aspek temporal pada motion graphic digunakan untuk membuat gerakan lebih halus dengan adanya frame per second (FPS). Penggunaan Fps pada sebuah video dapat menentukan berapa jumlah gambar statis yang kemudian diputar sehingga menghasilkan gerakan yang detail atau seberapa banyak frame yang ditampilkan dalam 1 detik. Aspek live action aspek ini lebih kepada penggunaan warna yang mampu mendukung terciptanya suasana emosional pada penonton, mengekspresikan ide cerita yang digabungkan dalam sebuah video dan didukung dengan gerakan animasi. Aspek typographic yaitu teknik memilih dan menyusun huruf untuk menciptakan kesan tertentu dalam menyampaikan sebuah pesan atau informasi. Ditunjukkan pada Gambar 7-9

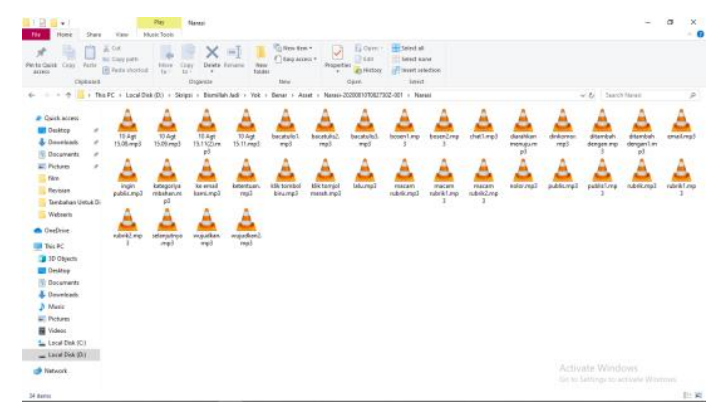

Gambar 7. Proses Dubbing

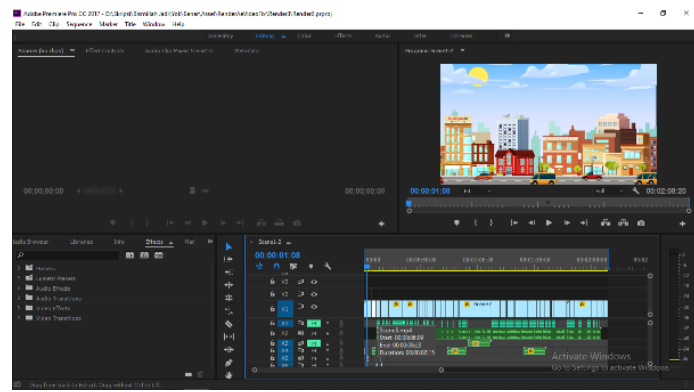

Gambar 8. Proses Editing

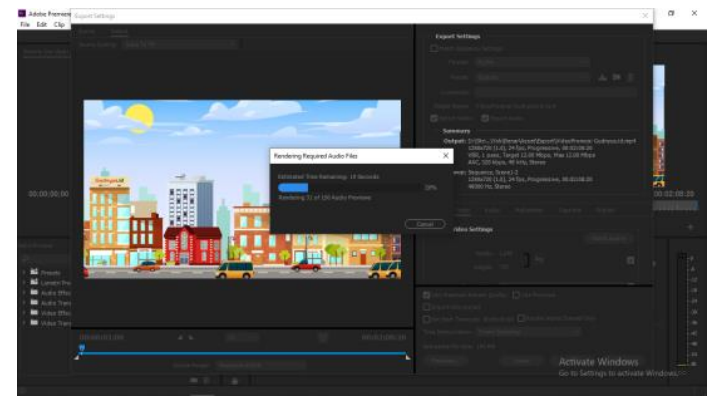

Gambar 9. Proses Rendering

\section{Pasca-Produksi}

Pada tahap ini pengembangan produk memasuki tahap pengujian Alpha Testing dan Beta Testing. Alpha testing akan diuji oleh reviewer media dan informasi, aspek yang digunakan pada reviewer media adalah aspek motion graphic menurut Krasner yaitu spatial, temporal, live action, typographic, untuk reviewer materi atau informasi menggunakan aspek yang berkaitan dengan informasi yang disampaikan dalam video promosi. Setelah dilakukan uji alpha, selanjutnya proses beta testing yang akan dilakukan oleh responden yaitu anak muda usia 19-34 tahun. Pada beta testing, aspek-aspek yang diuji adalah dari metode epic model seperti empati(empathy), persuasi (persuation), dampak(impact), dan komunikasi (communication).

\section{Delivery}

Pada tahap delivery akan dilakukan proses pengemasan produk berupa video berformat Mp4 dengan durasi waktu 2 menit 9 detik yang dilakukan publikasi produk melalui akun sosial media Gudnyus.id seperti youtube, facebook dan instagram sehingga video prmosi Gudnyus.id akan mudah dicari dan dilihat oleh masyarakat disajikan pada Gambar 10-12

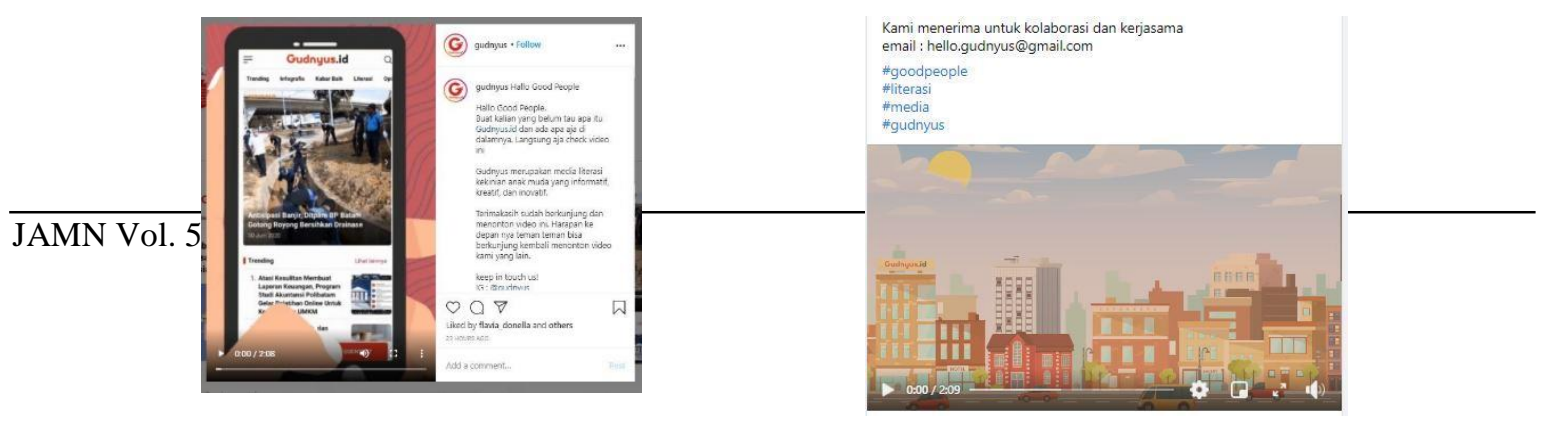




\section{Gambar 10. Tampilan Instagram Gudnyus.id Gambar 11. Tampilan Facebook Gudnyus.id}

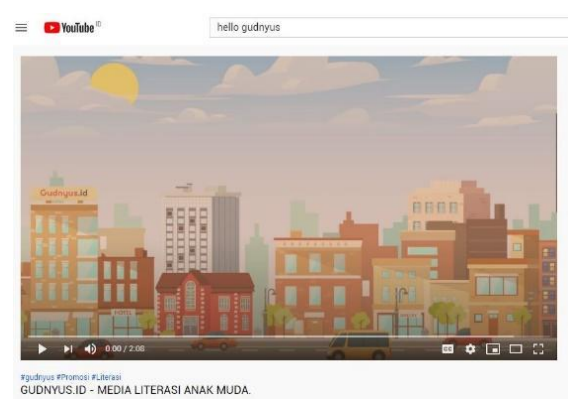

Gambar 12. Tampilan pada halaman Youtube Gudnyus.id

\section{Hasil Dan Pembahasan}

Penelitian ini membahas bagaimana cara membuat dan memiliki video promosi yang efektif untuk dipublikasi, pengujian efektivitas tersebut menggunakan metode epic model, metode ini merupakan model pengukuran akan tingkat efektivitas suatu produk, model epik dikembangkan oleh perusahaan riset pasar AC Nielsen yang bertujuan untuk mengukur dampak komunikasi yang ditinjau oleh empat ukuran kritis seperti: empati (Empathy), persuasi(Persuation), dampak(Impact),dankomunikasi(Communication) [6].

\section{a. Dimensi empati (Empathy)}

Berdasarkan Kamus Besar Bahasa Indonesia, empati adalah keadaan pikiran seseorang yang membuatnya merasa dirinya pada keadaan perasaan atau pikiran yang sama dengan orang atau suatu kelompok[7]. Pengertian empati adalah kemampuan komunikator untuk memahami apa yang dialami orang lain pada satu wakti dari sudut pandang yang berbeda [8].

\section{b. Dimensi persuasi (Persuation)}

Berdasarkan Kamus Besar Bahasa Indonesia persuasi adalah mengundang seseorang dengan memberikan alasan dan prospek yang baik dan menyakinkan [9]. Persuasi berasal dari bahasa latin "per sua dere" yang artinya membuat seseorang tergoda untuk melakukan sesuatu tanpa merasa terpaksa [10].

\section{c. Dimensi dampak (Impact)}

Pengeruh utama Kamus Besar Bahasa Indonesia adalah dampak pengaruh yang kuat dan hasil yang dibawanya bersifat negatif dan positif [11]. Pada tataran pengetahuan, pengaruh dapat berupa perubahan gagasan dan sudut pandang. Khalayak yang terpapar pada pesan promosi akan melakukan tindakan setelah melalui tahap awareness.

\section{d. Dimensi komunikasi (Communication)}

Komunikasi merupakan proses penyampaian informasi saat menyenbarkan informasi atau pesan melalui metode atau saluran komunikasi dengan koresponden yang dituju komunikasi dapat terjadi apabila kedua pihak dapat mengolah simbol dengan baik, simbol diartikan sebagai sebuah pesan dimana proses pengiriman dilakukan menggunakan media dan diubah [12].

Pengujian video promosi Gudnyus.id akan mengikuti dua tahap pengujian yaitu tahap alpha dan beta testing. Pada langkah alpha akan diuji oleh reviewer media dan materi yang terdiri dari 3 responden yang berkompeten pada bidangnya. Sedangkan untuk pengujian beta akan dilakukan kepada anak muda berusia 1934 tahun. Pengetesan akan dilakukan melalui kuesioner yang dibagian secara online melalui google formulir.

\section{Alpha Testing}

Alpha testing bertujuan untuk melakukan pengecekan video promosi oleh reviewer media dan materi, untuk mengetahui kesesuaian dari tiap aspek motion graphic apakah sudah sesuai dan kesesuaian materi yang 
dijadikan informasi di dalam video promosi apakah sudah sesuai dengan prosedur perusahaan (Gudnyus.id) dan yang ingin dipromosikan. Pengujian ini dilakukan dengan memberikan kuesioner yang berisi pernyataanpernyataan yang disesuaikan mengikuti aspek diatas dengan video promosi yang dibuat. Selanjutnya dihitung persentase dari setiap aspek didapatkan kesimpulan bahwa video promosi sudah sesuai dengan aspek-aspek diatas, setelah itu dilanjutkan ke tahap perhitungan, hasil yang didapat akan diputuskan sesuai dengan Tabel 4 Jarak Interval Penilaian.

Tabel 4. Jarak Interval Penilaian

\begin{tabular}{|l|c|}
\hline \multicolumn{1}{|c|}{ Kriteria } & Rentang Skala \\
\hline Sangat Tidak Setuju & $1.00-1.80$ \\
\hline Tidak Setuju & $1.81-2.60$ \\
\hline Cukup & $2.61-3.40$ \\
\hline Setuju & $3.41-4.20$ \\
\hline Sangat Setuju & $4.21-5.00$ \\
\hline
\end{tabular}

Jika penilaian terhadap video promosi Gudnyus.id mendapkan kriteria "Cukup" maka akan dilakukan perbaikan, apabila mendapatkan kriteria "Setuju", maka dapat diartikan bahwa video promosi yang dihasilkan dapat dijadikan bahan sebagai media promosi berdasarkan aspek-aspek yang diterapkan dan sudah dapat dipublikasikan. Persentase perhitungan tiap aspek alpha testing ditunjuk pada Tabel 5 dan Tabel 6 .

Tabel 5. Rincian Hasil Kuesioner Reviewer Media

\begin{tabular}{|c|c|c|c|c|c|c|}
\hline \multirow{2}{*}{ No } & \multirow{2}{*}{ Aspek } & \multicolumn{3}{|c|}{ Kode Penilai } & \multirow{2}{*}{$\begin{array}{l}\text { Jumlah } \\
\text { Pernyataan }\end{array}$} & \multirow{2}{*}{$\begin{array}{c}\text { Rata- } \\
\text { Rata } \\
\text { Kriteria }\end{array}$} \\
\hline & & Al & A2 & A3 & & \\
\hline \multicolumn{7}{|c|}{ Spatial } \\
\hline \multirow{3}{*}{1} & $\begin{array}{l}\text { Bentuk objek } \\
\text { mewakili ilustrasi } \\
\text { yang dibuat }\end{array}$ & 4 & 4 & 4 & 12 & 4 \\
\hline & $\begin{array}{l}\text { Gerakan antar objek } \\
\text { tidak mengganggu } \\
\text { satu dengan yang lain }\end{array}$ & 4 & 4 & 3 & 11 & 3.6 \\
\hline & $\begin{array}{l}\text { Tata letak objek jelas } \\
\text { untuk dilihat }\end{array}$ & 4 & 4 & 4 & 12 & 4 \\
\hline \multicolumn{7}{|c|}{ Temporal } \\
\hline \multirow{2}{*}{2} & $\begin{array}{l}\text { Tempo gerakan } \\
\text { animasi sudah tepat }\end{array}$ & 4 & 4 & 4 & 12 & 4 \\
\hline & $\begin{array}{l}\text { Transisi antar scene } \\
\text { jelas }\end{array}$ & 5 & 4 & 4 & 13 & 4.3 \\
\hline
\end{tabular}

\begin{tabular}{|c|l|c|c|c|c|c|}
\hline \multicolumn{7}{|c|}{ Live Action } \\
\hline \multirow{3}{*}{3} & $\begin{array}{l}\text { Warna latar belakang } \\
\text { sudah tepat }\end{array}$ & 4 & 4 & 4 & 12 & 4 \\
\cline { 1 - 6 } & $\begin{array}{l}\text { Objek animasi terlihat } \\
\text { dengan jelas }\end{array}$ & 3 & 4 & 5 & 12 & 4 \\
\cline { 2 - 5 } & $\begin{array}{l}\text { Sudut pandang } \\
\text { kamera terhadap } \\
\text { objek sudah tepat }\end{array}$ & 4 & 4 & 4 & 12 & 4 \\
\hline
\end{tabular}

\begin{tabular}{|c|l|c|c|c|c|c|}
\hline \multicolumn{7}{|c|}{ Typhography } \\
\hline \multirow{4}{*}{$\mathbf{4}$} & $\begin{array}{l}\text { Ukuran font yang } \\
\text { digunakan dapat } \\
\text { dibaca }\end{array}$ & 4 & 4 & 4 & 12 & 4 \\
\cline { 2 - 7 } & $\begin{array}{l}\text { Jenis font yang } \\
\text { digunakan dapat } \\
\text { dibaca }\end{array}$ & 4 & 4 & 4 & 12 & 4 \\
\hline Jumlah & $\mathbf{4 0}$ & $\mathbf{4 0}$ & $\mathbf{4 0}$ & $\mathbf{1 2 0}$ & $\mathbf{4 0}$ \\
\hline Rata-Rata & $\mathbf{4 . 0}$ & $\mathbf{4 . 0}$ & $\mathbf{4 . 0}$ & $\mathbf{1 2 . 0}$ & $\mathbf{4 . 0}$ \\
\hline Keterangan & $\mathbf{S}$ & $\mathbf{S}$ & $\mathbf{S}$ & & $\mathbf{S}$ \\
\hline
\end{tabular}

Setelah mengetahui hasil dari Tabel 5 didapatkan nilai dari pernyataan yang diisi oleh reviewer dengan inisial A1-A3 dengan rata-rata 4.0 dari setiap pernyataan, hal ini didapat dari menjumlahkan setiap skor jawaban reviewer lalu dibagi dengan jumlah pernyataan. Skor 4.0 masuk dalam kategori (S(Setuju)) hal ini 
sesuai dengan jarak interval penilaian. Dengan demikian media promosi Gudnyus.id dalam bentuk motion graphic telah memenuhi aspek-aspek motion graphic yang diterapkan dalam pembuatannya, sehingga dapat dipublikasikan.

Tabel 6. Rincian Hasil Kuesioner Reviewer Materi

\begin{tabular}{|c|l|c|c|c|c|c|}
\hline \multicolumn{7}{|c|}{ Informasi } \\
\hline & $\begin{array}{l}\text { Apakah Penyajian } \\
\text { visual sesuai } \\
\text { kebutuhan perusahaan }\end{array}$ & 4 & 4 & 5 & 13 & 4.3 \\
\hline $\begin{array}{l}\text { Apakah informasi yang } \\
\text { disampaikan sesuai } \\
\text { dengan kenyataan }\end{array}$ & 4 & 4 & 4 & 12 & 4 \\
\hline $\begin{array}{l}\text { Apakah kedalaman } \\
\text { informasi promosi } \\
\text { yang disampaikan } \\
\text { sudah sesuai } \\
\text { kebutuhan }\end{array}$ & 4 & 3 & 4 & 11 & 3.6 \\
\hline $\begin{array}{l}\text { Apakah penempatan } \\
\text { ikon, logo, dan grafis } \\
\text { lain sesuai kebutuhan } \\
\text { perusahaan }\end{array}$ & 3 & 4 & 4 & 11 & 3.6 \\
\hline $\begin{array}{l}\text { Apakah Peyajian } \\
\text { informasi mudah } \\
\text { dimengerti }\end{array}$ & 4 & 4 & 4 & 12 & 4 \\
\hline
\end{tabular}

\begin{tabular}{|c|c|c|c|c|c|c|}
\hline \multicolumn{7}{|c|}{ Promosi } \\
\hline \multirow{3}{*}{3} & $\begin{array}{l}\text { Apakah kontak } \\
\text { Gudnyus.id sudah } \\
\text { sesuai kebutuhan } \\
\text { perusahaan }\end{array}$ & 5 & 5 & 4 & 14 & 4.6 \\
\hline & $\begin{array}{l}\text { Apakah informasi yang } \\
\text { disampakai sesuai } \\
\text { dengan yang dituju }\end{array}$ & 4 & 4 & 4 & 12 & 4 \\
\hline & $\begin{array}{l}\text { Apakah ketepatan } \\
\text { aspek - aspek } \\
\text { pendukung sudah } \\
\text { sesuai kebutuhan } \\
\text { perusahaan] }\end{array}$ & 4 & 4 & 3 & 11 & 3.6 \\
\hline & Jumlah & 41 & 40 & 40 & 121 & 40.3 \\
\hline & Rata-Rata & 4.1 & 4.0 & 4.0 & 12.1 & 4.3 \\
\hline & Keterangan & $\mathrm{S}$ & $\mathbf{S}$ & $\mathbf{S}$ & & $\mathrm{S}$ \\
\hline
\end{tabular}

Setelah mengetahui hasil dari Tabel 6 didapatkan nilai dari pernyataan yang di isi oleh reviewer dengan inisial A1-A3 dengan rata-rata 4.1 dari setiap pernyataan, hal ini didapat dari menjumlahkan setiap skor jawaban reviewer lalu dibagi dengan jumlah pernyataan. Skor 4.1 masuk dalam kategori (S(Setuju)) hal ini sesuai dengan jarak interval penilaian. Dengan demikian media promosi Gudnyus.id telah memenuhi standar perusahaan mengenai informasi yang ingin disampaikan pada pembuatan video promosi hal ini video promosi dapat dipublikasikan.

\section{Beta Testing}

Tahap beta testing dilakukan terhadap 30 responden yaitu anak muda usia 19-34 tahun yang mengacu pada pernyataan 4 dimensi kritis epic model. Pengujian beta dilakukan dengan menyebarkan kuesioner yang disebarkan secara online. Untuk memutuskan hasil, nantinya akan digunakan rentang skala keputusan epic model yang ditunjuk kepada Tabel 7.

Tabel 7. Rentang skala keputusan epic model 


\begin{tabular}{|l|c|}
\hline \multicolumn{1}{|c|}{ Kategori } & Jarak Skala \\
\hline Sangat Tidak Efektif & $1.00-1.80$ \\
\hline Tidak Efektif & $1.81-2.60$ \\
\hline Cukup Efektif & $2.61-3.40$ \\
\hline Efektif & $3.41-4.20$ \\
\hline Sangat Efektif & $4.20-5.00$ \\
\hline
\end{tabular}

Apabila penilaian terhadap video promosi Gudnyus.id mendapkan kriteria "Cukup" maka akan dilakukan perbaikan, jika mendapatkan kriteria "setuju", maka dapat diartikan bahwa video promosi yang dibuat sudah Efektif. Hasil rata-rata perhitungan tiap dimensi pada beta testing dalam kuesioner adalah empathy 4,05, persuation 4,26, impact 4, communication 4,2, dengan epic rate 4,1347.

Dari hasil perhitungan pengukuran efektivitas motion graphic sebagai media promosi Gudnyus.id melalui epic model (Empathy, Persuasion, Impact and Communication) maka didapatlah sebuah grafik, secara keseluruhan yang dirujuk pada Gambar 13.

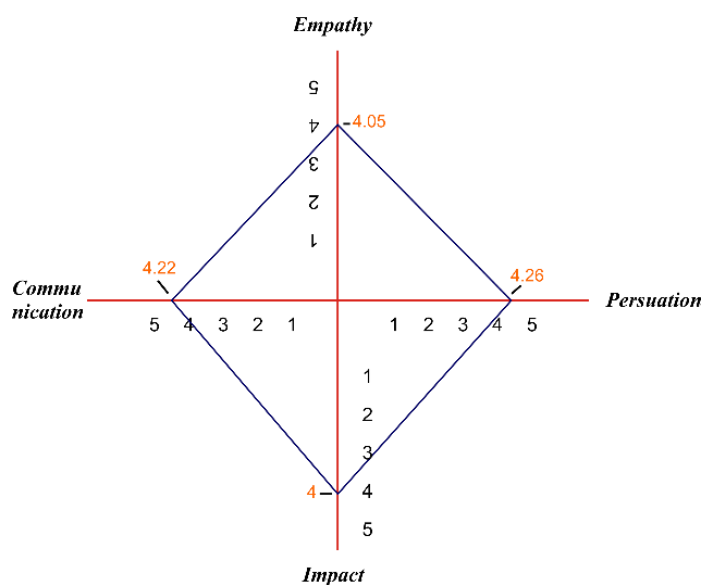

Gambar 13. Grafik Epic Model

Grafik diatas menunjukan empat dimensi epic Model (empathy, persuation, impact dan Communication) dengan hasil pengukuran efektifitas media promosi Gudnyus.id dinyatakan Efektif. Nilai yang memiliki efektifitas menonjol pada dimensi Communication dan Persuation yaitu 4,22 dan 4,26 sedangkan nilai ratarata Empathy 4,05 dan Impact 4,0. Dapat disimpulkan bahwa video promosi Gudnyus.id berbasis motion graphic dapat dinyatakan Efektif dengan nilai rata-rata dari keempat dimensi kritis yaitu 4,0895, hal ini memposisikan nilai rata-rata video promosi Gudnyus.id pada posisi Efektif sesuai dengan rentang skala keputusan Epic Model.

\section{Kesimpulan}

Pembuatan video promosi Gudnyus.id menggunakan metode Villamil Molina sebagai metode perancang kelima tahap tersebut adalah development, pre-production, production, post-production, delivery dengan hasil berupa video berformat Mp4 ditambah dengan metode model epik dengan empat dimensi utama yaitu empathy, persuation, impact, dan communication sebagai penguji tingkat efektivitas dari video promosi yang dibuat dengan hasil perhitungan kuesioner empat dimensi dengan rata-rata Empathy 4,05, Persuation 4,26, Impact 
4,0 dan Communication 4,22. Dengan hal ini video promosi Gudnyus,id dinyatakan efektif untuk dapat disebarluaskan.

\section{Acknowledgment}

Terimakasih atas berkat rahmat Allah SWT dan penghargaan setinggi-tingginya kepada Ibu Arta Uly Siahaan sebagai pembimbing Penulis, untuk segala koreksi, perhatian, tenaga, juga masukan untuk penulis dalam proses penulisan ini.

\section{Daftar Pustaka}

[1] Lamb, Charles W.,Hair, Joseph F., dan Mcdaniel . 2001. Pemasaran Buku I.

[2] Jakarta: Salemba Empat

[3] Adi, R. N., \& WIDIYANTO, I. (2013). Analisis Faktor-Faktor yang Mempengaruhi Keputusan Pembelian dengan Sistem Pre Order Secara Online (Studi Kasus Pada Online Shop Chopper Jersey) (Doctoral Dissertation, Fakultas Ekonomika dan Bisnis).D. Author 4, et. al., Book number one, Prentice Hall Inc., New York, USA, 2009.

[4] E. Author5, "InBook number one", in Book number two, (Eds.: F. Author6 and G. Author7), Springer, Berlin, Germany, pp. xxxx-xxxx, 2009.

[5] Sukarno, I. S. 2008. Perancangan Motion graphic Ilustratif Mengenai Majapahit untuk Pemuda-Pemudi, Fakultas Seni Rupa dan Desain ITB.

[6] Villamil, J. Molina. L. 1997. Multimedia: Production, Planning, and delivery, Que Education \& Training. United States: Prentice Hall.

[7] Durianto, D., Sugiarto., Widjaja,A.W., \& Supratikno, H. Invasi Pasar dengan Iklan yang Efektif. (Jakarta: PT. Gramedia Pustaka Utama, 2003).

[8] Departemen Pendidikan Nasional. (2008). Kamus Besar Bahasa Indonesia Pusat Bahasa. Edisi ke-4. Gramedia: Jakarta

[9] Suprapto, T. Teknik Jitu Persuasi dan Negosiasi. (Yogyakarta: MedPress, 2008). Suroyo, Anwar. 2009. Pemahaman Individu; Observasi, Checklist, Kuesioner dan Sosiometri. Semarang : Widya Karya.

[10] Departemen Pendidikan Nasional. (2008). Kamus Besar Bahasa Indonesia Pusat Bahasa. Edisi ke-4. Gramedia: Jakarta

[11] Sastropoetro, S. Partisipasi, Komunikasi, Persuasi, dan Disiplin dalam Pembangunan Nasional. (Bandung: PT. Alumni, 2008).

[12] Departemen Pendidikan Nasional. (2008). Kamus Besar Bahasa Indonesia Pusat Bahasa. Edisi ke-4. Gramedia: Jakarta 